Akademia im. Jakuba z Paradyża w Gorzowie Wielkopolskim

\title{
Marek Kaszewski, Studia z leksykografii historycznej. Wydanie 2. rozszerzone, Towarzystwo Autorów i Wydawców Prac Naukowych UNIVERSITAS, Kra- ków 2016, ss. 194
}

Towarzystwo UNIVERSITAS zdecydowało się na drugie, rozszerzone wydanie książki Marka Kaszewskiego Studia z leksykografii historycznej. Oprócz studiów pomieszczonych w pierwszym wydaniu (Kraków 2014), obejmujących przeważna część książki (s. 7-128), w wydaniu „rozszerzonym” znalazły się trzy nowe studia: o regionalizmach leksykalnych w słowniku (Bogactwa mowy polskiej) Alojzego Osińskiego, o formacjach słowotwórczych w słowniku Mikołaja Volckmara z roku 1596 i o formalnej zbieżności nazw narzędzi i nazw wykonawców czynności w słownikach XVI-XVIII wieku (s. 129-184).

Decyzję zasłużonego Towarzystwa należy uznać za uzasadnioną i powitać z zadowoleniem. W kontekście „rozszerzenia” książki tym bardziej przekonująco brzmi założenie (teza) autora, z którym musi się zgodzić każdy historyk języka:

\begin{abstract}
Jak wiadomo, słowniki historyczne są nieocenionym źródłem materiału językowego, mogącego w zasadniczy sposób służyć celom badawczym, zakrojonym na szeroką skalę studiom o charakterze ogólnohumanistycznym, ale także stanowią niezwykle ważny rezerwuar wiedzy na temat świadomości językowej autorów owych dzieł, która w mniej lub bardziej miarodajny sposób odzwierciedla między innymi świadomość współczesnych leksykografom użytkowników języka. Za istotne dla językoznawstwa należy uznać wszelkie prace porównawcze nad leksykografią historyczną - porównywanie ze sobą różnych słowników dawnej polszczyzny pozwala nie tylko poszerzyć wiedzę na temat stanu leksykalnego czasów dawnych i (...) pozyskać niezwykle bogaty zasób wiedzy, który kumuluje się w informacji gramatycznej, kwalifikatorach, ilustracjach kontekstowych oraz innych miejscach, w których może ujawnić się indywidualna koncepcja leksykograficzna danego autora (...) (s. 9).
\end{abstract}

Nie ulega najmniejszej wątpliwości, że dzieje leksykografii stanowią istotny fragment historii języka. Jest tak całkiem po prostu dlatego, że leksykografia - obok edytorstwa naukowego - dostarcza historii języka podstaw źródłowo-materiałowych. Stanowią te podstawy z jednej strony teksty (i tu się ujawnia rola edytorstwa naukowego), a z drugiej słowniki: i stąd wielka rola badań w zakresie dziejów leksykografii, które trzeba traktować jako podstawowe, fundamentalne badania historycznojęzykowe. 
Tymczasem, jak słusznie przypomina autor recenzowanej pracy, badania te wykazują różny w odróżnieniu do różnych okresów historii języka polskiego stopień zaawansowania. By nie wchodzić w szczegóły - o ile dysponujemy już dziś wyczerpującymi (w zasadzie monograficznymi) opisami najważniejszych słowników średniowiecznych i szesnastowiecznych (Bartłomieja z Bydgoszczy, Murmeliusza i Mymera, Jana Cervusa z Tucholi, a przede wszystkim Jana Mączyńskiego), a z siedemnastowiecznych - działu polskiego w słowniku Piotra Lodereckera i wielkiego dzieła Grzegorza Knapiusza (choć co do Knapiusza, mimo licznych prac Jadwigi Puzyniny, można by mieć pewne wątpliwości - nie znamy dotąd, na co zwracał uwagę mój mistrz naukowy, Władysław Kuraszkiewicz, pełnego rejestru polskich wyrazów w Thesaurusie: wprawdzie polszczyzna jest w nim na pierwszym miejscu, ale sporo haseł polskich opatrzył Knapiusz (przed odpowiednikami łacińskimi i greckimi) objaśnieniami polskimi, których wyrazy nie zawsze figurują w Thesaurusie jako hasła - jest więc zasadne opracowanie, paralelne do Kuraszkiewiczowskiego odnośnie do Leksykonu Mączyńskiego, wyrazów polskich w Thesaurusie Knapiusza). Później wyczerpująco są opisane słowniki: Lindego (w dużej mierze dzięki studiom Tadeusza Lewaszkiewicza), Mrongowiusza (Bogusław Nowowiejski), wileński (Bogdan Walczak), warszawski (Magdalena Majdak), Doroszewskiego, Szymczaka i niektóre współczesne, natomiast wciąż jeszcze niesatysfakcjonująca jest nasza wiedza o polskim dziale w najgłośniejszym renesansowym słowniku Calepina, a zwłaszcza w dziełach Daneta-Koli, Trotza, Bandtkiego i Osińskiego (w odniesieniu do nich istniejące opracowania wciąż jeszcze mają charakter rekonesansowy). W tej sytuacji pożądane są wszelkie na ten temat studia, a Marek Kaszewski wyrasta na najlepszego znawcę leksykografii doby średniopolskiej i początków nowopolskiej.

Należy jednak podkreślić, że wartość recenzowanej książki nie ogranicza się do tego, że dotyczy relatywnie najsłabiej znanych słowników (głównie Volckmara, Trotza, Bandtkiego i Osińskiego), wypełnia więc dotkliwą lukę w literaturze naukowej. Stanowią o tej wartości jeszcze takie aspekty i okoliczności jak:

1) Filologiczna akrybia i precyzja autora, wyrażająca się m.in. ścisłą transliteracją haseł i cytatów.

2) Wnikliwość analizy i interpretacji (autor ujawnia wiele nowych, dotąd w nauce nie dyskutowanych cech uwzględnionych dzieł leksykograficznych).

3) Gruntowna wiedza metaleksykograficzna autora (skutkująca skupieniem uwagi na takich kluczowych elementach mikrostruktury słowników jak informacja gramatyczna czy kwalifikatory).

4) Umiejętne (tam, gdzie jest to zasadne) wyzyskanie zalet metodologicznych językoznawstwa statystycznego.

5) Walory warsztatu naukowego autora, charakteryzującego się wielu cennymi i pożądanymi, a rzadkimi dziś zaletami, jak choćby ostrożność w wyciąganiu wniosków i formułowaniu tez (mimo bardzo solidnych podstaw źródłowo-materiałowych).

Merytorycznie praca jest bez zarzutu. Można podziwiać chwalebną powściągliwość autora, który bez komentarza przywołał (w przypisie 23. na s. 42) opinię Andrzeja Bańkowskiego (z jego Etymologicznego słownika języka polskiego) o tym, że słownik Lindego jest ,....) pośpiesznie łatany niezliczonymi pożyczkami ze słowniczka Bandtkiego (zwykle z zatajeniem ich źródła) (...)" (Bańkowski s. XIV; wiadomo, że Bańkowski absurdalnie i maniakalnie głosił pogląd o wyższości Bandtkiego nad Lindem, więcej: uważał słownik 
Bandtkiego za największe osiągnięcie polskiej leksykografii (,(...) nie ma sobie równych po dziś dzień (...)" (Bańkowski s. XIV); jest to jedna z osobliwych tez Bańkowskiego, tyleż warta, co jego sąd (z tegoż Etymologicznego słownika języka polskiego) o Janie Kochanowskim, biedaku czarnoleskim, który ,(...) pisał sobie i muzom pod lipą, pięknie naśladując Horacego swoją parafiańską gwarą, a jego wiersze zaczęto popularyzować dopiero w dobie kontrreformacji, i nie dla ich walorów, ale dlatego, że poeta należał do tych kilku jedynych, którzy wytrwali w papizmie do śmierci”) (Bańkowski s. XXXIX).

Przydatna dla historyka języka książka Marka Kaszewskiego zasługuje w przyszłości na dalsze ,rozszerzanie”. 